\title{
Perbedaan Paparan Tungau Debu Rumah dengan Status Rhinitis Alergi Berdasarkan Kriteria ISAAC pada Anak di Dua Panti Asuhan Kecamatan Koto Tangah.
}

\author{
Dwi Fitria Nova ${ }^{1}$, Selfi Renita Rusjdi ${ }^{2}$, Fachzi Fitri ${ }^{3}$
}

Abstrak

Tungau Debu Rumah (TDR) merupakan tungau yang berasal dari famili Pyroglyphidae yang hidup bersama debu rumah. TDR memiliki feses yang dapat menimbulkan penyakit alergi yang salah satunya rhinitis alergi. Rhinitis alergi muncul sekitar 15\% anak usia 6-7 tahun dan 40\% pada 13-14 tahun. International Study of Asthma and Allergies of Childhood (ISAAC) merupakan organisasi dunia yang melakukan studi prevalensi rhinitis alergi dengan menggunakan kuesioner yang telah distandarisasi. Tujuan penelitian ini adalah untuk mengetahui perbedaan paparan tungau debu rumah dengan status rhinitis alergi berdasarkan kuesioner ISAAC pada anak. Penelitian ini merupakan cross sectional study yang dilakukan di Panti asuhan Kecamatan Koto Tangah dari November 2017 sampai Januari 2018. Teknik pengambilan sampel secara total sampling. Debu tempat tidur diambil dengan vacum cleaner dan dilakukan wawancara dengan menggunakan kuesioner ISAAC. Debu diperiksa di laboratorium Parasitologi Fk Unand. Dari penelitian didapatkan 41 sampel. Famili terbanyak adalah Famili Pyrogliphydae yaitu 34,6\% (81 tungau). Individu dengan rhinitis alergi berdasarkan kuesioner ISAAC berjumlah 17 orang (41,5\%). Kepadatan TDR pada penderita rhintis alergi yaitu 6.29 tungau dan non rhinitis alergi sebanyak 6.33 tungau. Simpulan adalah tidak terdapat perbedaan bermakna antarapaparan tungau debu rumah dengan status rhinitis alergi pada anak.

Kata kunci: TDR, rinitis alergi, kuesioner ISAAC

\begin{abstract}
House dust mites (HDM) is mites that belongs to Phyrogliphidae family. HDM have feces and alergenic organ that induce several allergic diseases such as allergic rhinitis. This disease appears approximately $15 \%$ on children aged 6-7 year old and 40\% on 13-14 year old. International Study of Asthma and Allergies of Childhood (ISAAC) is world organization that perform studies on allergic rhinitis prevalence using standardized questionnaire. The objective of this study was to know the differences exposure of house dust mites with rhinitis allergic status based on ISAAC questionnaire in the children. This cross sectional study took place in orphanage in Kecamatan Koto Tangah on November $17^{\text {th }}$ until December $18^{\text {th }}$. The sampling technique for this study is total sampling. The dust was taken from the bed using vacum cleaner and interviewed by using ISAAC questionnaire. The dust was examined in Parasitology's Laboratory in Medical Faculty of Andalas University. From this study 41 sample is obtained. Famili Pyrogliphidae is the most were found which is 34,6\% (81 mites) in this study. There is 17 persons (41,5\%) who have allergic rhinitis based on ISAAC questionnaire. The density of house dust mites in allergic rhinitis patients is 6,29 mites and non allergic rhinitis is 6.33 mites. It can be concluded from this study that there is no significant differences between the exposure of house dust mites with rhinitis allergic status based on ISAAC questionnaire in the children.
\end{abstract}

Keywords: HDM, density, allergic rhinitis, ISAAC questionnaire

Affiliasi penulis: 1. Prodi Kedokteran Fakultas Kedokteran Universitas Andalas Padang (FK Unand), 2. Bagian Parasitologi FK Unand, 3. Bagian THT-KL FK Unand/RSUP Dr. M. Djamil Padang
Korespondensi: Dwi Fitria Nova, Email: dwifitrianova18@gmail.com Telp: 082169838334 


\section{PENDAHULUAN}

Tungau Debu Rumah (TDR) merupakan tungau yang berasal dari filum Arthropoda, kelas Arachnida, ordo Acarina, subordo Astigmata, dan famili Pyroglyphidae yang biasanya hidup bersama debu rumah sehingga sering disebut tungau debu rumah. ${ }^{1}$ Spesies lain yang paling sering ditemukan khususnya daerah tropis dan subtropis adalah famili Glycypaghidae yaitu Blomia Tropicalis. ${ }^{2}$

Pyroglyphidae merupakan famili yang paling sering ditemukan. Beberapa spesies yang memiliki hubungan erat dengan kejadian alergi diantaranya Dermatophagoides (D) pteronyssinus, D. farinae, Euroglyphus maynei, $D$. microceras. ${ }^{3} \quad D$ pteronyssinus, $D$ farinae, Euroglyphus maynei dan Blomia tropicalis merupakan spesies yang rata-rata terdapat pada daerah beriklim sedang atau tropis di dunia. ${ }^{4}$ Menurut WHO, sekitar 50-80 \% asma dan rhinitis di seluruh dunia disebabkan oleh tungau debu rumah khususnya $D$. pteronyssinus dan $D$. farinae. ${ }^{5}$

Kasur merupakan habitat terbaik untuk perkembangan TDR karena TDR menyukai lingkungan yang hangat dan lembab seperti di dalam kasur. Kepadatan populasi TDR juga dipengaruhi oleh jenis kasur. Penelitian perbandingan populasi TDR antara kasur kapuk dengan kasur non kapuk di komplek perumahan PJKA kelurahan Randusari, Semarang Selatan, Jawa Tengah didapatkan perbedaan yang sangat bermakna antara populasi TDR pada kasur kapuk dan pada kasur non kapuk. ${ }^{6}$ TDR tidak menggigit akan tetapi feses dan organ yang alergenik ini yang akan terinhalasi atau tertelan sehingga mengakibatkan penyakit alergi berupa rhinitis alergi, dermatitis atopik dan asma. ${ }^{7}$ Rhinitis alergi merupakan penyakit terkait imunoglobulin $E$ $(\lg E)$ yang paling sering ditemukan. Berdasarkan studi epidemiologi didapatkan prevalensi rhinitis alergi sekitar $10-20 \%$ di Amerika serikat. Rhinitis didefinisikan sebagai peradangan mukosa hidung yang ditandai dengan bersin-bersin, hidung tersumbat dan rhinorea. ${ }^{8}$

Rhinitis alergi yang berat sangat berpengaruh terhadap kualitas hidup, tidur dan bekerja. ${ }^{9}$ Rhinitis alergi mempengaruhi $10-40 \%$ dari anak-anak di seluruh dunia dan cenderung meningkat jumlahnya.
Rhinitis dapat menyebabkan rhinosinusitis, otitis media dan gangguan pendengaran (sekunder karena disfungsi tuba Eustachian), gangguan tidur dan konsekuensi buruk untuk kinerja kognitif/sekolah. ${ }^{10}$ Penelitian yang dilakukan oleh Utama di Sub Bagian Alergi Imunologi Kinik THT-KL RSUP Dr. Kariadi Semarang dengan menggunakan uji cukit kulit menunjukkan 83,8\% TDR menjadi aeroalergen yang diduga menjadi pemicu timbulnya gejala rhinitis alergi. ${ }^{11}$

International Study of Asthma and Allergies of Childhood (ISAAC) merupakan organisasi dunia yang melakukan studi prevalensi rhinitis alergi dengan menggunakan kuesioner yang telah distandarisasi. ${ }^{12}$

Penelitian ini dilakukan di 2 panti asuhan Kecamatan Koto Tangah, kota Padang. Panti asuhan menjadi sasaran penelitian karena panti asuhan pada umumnya menjadi sumber beberapa penyakit. Selain faktor jumlah penghuni yang cukup padat, terdapat juga kurangnya kesadaran akan kebersihan kamar tidur, sehingga biasanya jarang dilakukan penjemuran kasur, pergantian alas kasur yang kurang dari 2 minggu dan pembersihan debu dengan vacum cleaner.

\section{METODE}

Jenis penelitian ini adalah cross sectional study dengan rancangan yaitu subyek penelitian diobservasi sebanyak satu kali dan variabel diukur langsung pada pemeriksaan tersebut. Variabel independennya adalah paparan tungau debu rumah dan variabel dependennya adalah anak dengan rhinitis alergi dan tidak rhinitis alergi di dua Panti asuhan Kecamatan Koto Tangah.

Populasi penelitian adalah tempat tidur beserta penghuni panti asuhan yang sesuai kriteria inklusi. Sampel penelitian yang dipilih yaitu tempat tidur beserta penghuni panti asuhan yang memenuhi kriteria inklusi dan eksklusi. Kriteria inklusi: Panti asuhan yang bersedia untuk diambil sampel, penghuni Panti asuhan yang berusia 6-14 Tahun dan sudah tinggal minimal 5 bulan. Kriteria eksklusi: Tempat tidur yang alas kasur baru digunakan minimal 3 hari, kasur yang sudah tidak dipakai untuk tidur. 
Data diperoleh dengan cara mengambil sampel debu dengan menggunakan vacuum cleaner dan wawancara menggunakan kuesioner International Study of Asthma and Allergies of Childhood (ISAAC). Sampel debu diperiksa di Laboratorium Parasitologi FK Unand. Intepretasi hasil wawancara yaitu ada atau tidaknya rhinitis alergi.

Data dianalisis secara statistik berdasarkan variabel yang dinilai menggunakan sistem komputerisasi yaitu analisis univariat dan bivariat. Analisis univariat dilakukan untuk melihat distribusi frekuensi dari masing-masing variabel independen dan variabel dependen. Analisis bivariat dilakukan untuk menganalisis perbedaan antara variabel independen dan variabel dependen. Perbedaan dua variabel tersebut dianalisis dengan menggunakan uji $t$ dan dikatakan bermakna bila $\mathrm{p}<0.05$.

\section{HASIL}

Sampel penelitian ini berjumlah 41 sampel yang telah memenuhi kriteria inklusi dan eksklusi. Panti asuhan yang diambil yaitu Panti asuhan AlFalah dan Aisyiah karena kedua panti tersebut yang memenuhi kriteria inklusi sampel. Penelitian ini dilakukan pada bulan Desember 2017 - Februari 2018.

Tabel 1. Distribusi frekuensi Tungau Debu Rumah (TDR) berdasarkan jenis tungau

\begin{tabular}{lcc}
\hline \multicolumn{1}{c}{ Jenis tungau } & Jumlah & $\%$ \\
\hline 1.Famili Pyroglypidae & 81 & $34.6 \%$ \\
2.Famili Glycyphagidae & 77 & $32.9 \%$ \\
3.Famili Chortoglypidae & 26 & $11.1 \%$ \\
PROSTIGMATA & & \\
1. Family Cheyletidae & 5 & $2.13 \%$ \\
2. Famili Tarsonomidae & 6 & $2.57 \%$ \\
Tungau yang tidak & 39 & $16.7 \%$ \\
teridentifikasi & & \\
\hline \multicolumn{1}{c}{ Jumlah } & 234 & $100 \%$ \\
\hline
\end{tabular}

Berdasarkan hasil identifikasi didapatkan jenis tungau terbanyak yang ditemukan adalah famili Pyroglypidae yaitu sebesar 34.6 \% (81 ekor tungau) dan familiGlycyphagidae yaitu $32.9 \%$ (77 ekor tungau). Famili Chortoglypidae didapatkan 11.1\% (26 ekor tungau). Famili yang paling sedikit ditemukan adalah famili Cheyletidae yaitu sebesar $2.13 \%$ (5 ekor tungau). Hasil identifikasi famili Tarsonomidae didapatkan hasil $2.57 \%$ (6 ekor tungau) dan tungau yang tidak dapat teridentifikasi sebanyak $16.7 \%$ (39 ekor tungau). Tungau tidak teridentifikasi karena bentuk tungau yang tidak utuh saat diidentifikasi di bawah mikroskop.

Tabel 2. Kepadatan tungau debu rumah berdasarkan jenis kasur

\begin{tabular}{lrc}
\hline $\begin{array}{l}\text { Jenis } \\
\text { kasur }\end{array}$ & Jumlah & $\%$ \\
\hline Kasur kapuk & 136 & $58.11 \%$ \\
Kasur non kapuk & 98 & $41.89 \%$ \\
\hline Jumlah & 234 & $100 \%$ \\
\hline
\end{tabular}

Berdasarkan tabel diatas didapatkan bahwa jenis kasur kapuk memiliki jumlah TDR yang lebih banyak yaitu sebesar $58.11 \%$ (136 ekor tungau), dibandingkan kasur non kapuk yaitu sebesar $41.89 \%$ (98 ekor tungau). Walaupun terdapat perbedaan jumlah tungau antara kasur kapuk dengan non kapuk, namun perbedaaan tersebut tidak bermakna.

Tabel 3. Kepadatan tungau debu rumah di panti asuhan Kecamatan Koto Tangah

\begin{tabular}{lc}
\hline \multicolumn{1}{c}{ Kepadatan TDR } \\
\hline Jumlah tungau & 234 \\
Berat total debu (gram) & 4.92 \\
Kepadatan tungau & 94.5 \\
( per gram debu ) & \\
\hline
\end{tabular}

Tabel 3 menunjukkan kepadatan tungau debu rumah secara keseluruhan. Kepadatan tungau debu rumah dari sampel debu yang diambil di panti asuhan Kecamatan Koto Tangah didapatkan hasil 94.5 tungau/gram debu. 
Tabel 4. Karakteristik responden di di panti asuhan Kecamatan Koto Tangah

\begin{tabular}{ccc}
\hline Karakteristik & Jumlah & $\%$ \\
\hline Jenis Kelamin & 1 & $5.8 \%$ \\
Laki-Laki & 16 & $94.2 \%$ \\
Perempuan & & \\
Usia (tahun) & 3 & $17.7 \%$ \\
$6-10$ & 14 & $82.3 \%$ \\
$11-14$ & & \\
\hline Jumlah & 17 & $100 \%$ \\
\hline
\end{tabular}

Tabel diatas menunjukkan bahwa individu dengan rhinitis alergi berdasarkan kriteria ISAAC terbanyak yaitu pada usia 11-14 tahun yaitu sebesar $82.3 \%$ (14 orang). Rhinitis alergi paling banyak terjadi pada wanita yaitu sebesar $94.2 \%$ (16 orang).

Tabel 5. Perbedaan paparan tungau debu rumah dengan status rhinitis alergi berdasarkan kuesioner ISAAC pada anak di panti asuhan Kecamatan Koto Tangah.

\begin{tabular}{|c|c|c|}
\hline Kepadatan & $\begin{array}{l}\text { Kejadian rhinitis alergi } \\
\text { berdasarkan kriteria } \\
\text { ISAAC }\end{array}$ & \\
\hline $\begin{array}{l}\text { tungau debu } \\
\text { rumah }\end{array}$ & Rhinitis(+) $\quad$ Rhinitis(-) & $\mathbf{p}$ \\
\hline $\begin{array}{l}\text { Rerata } \\
\text { Kepadatan } \\
\text { tungau debu rumah }\end{array}$ & $6.29 \pm 4.135 \quad 6.33 \pm 3.619$ & 0.8 \\
\hline
\end{tabular}

Berdasarkan Tabel 5 diatas diketahui kepadatan rata- rata tungau debu rumah pada individu tanpa riwayat rhinitis alergi adalah sebesar 6.33 tungau/gram debu sedangkan pada individu dengan riwayat rhinitis alergi memiliki kepadatan rata-rata tungau debu rumah sebanyak 6.29 tungau/gram debu.

Perbedaan paparan Tungau Debu Rumah (TDR) pada kelompok anak dengan rhinitis alergi dan tidak rhinitis alergi berdasarkan kriteria ISAAC di 2 Panti Asuhan Kecamatan Koto Tangah, Kota Padang diatas maka dilakukan uji hipotesis dengan menggunakan t-test. Hasil uji didapatkan nilai $\mathrm{p}$ sebesar 0.8 , yang berarti nilai $p>0.05$ sehingga menurut diagnosis statistik dapat disimpulkan tidak terdapat perbedaan bermakna rerata paparan Tungau Debu Rumah (TDR) dengan status rhinitis alergi berdasarkan kuesioner ISAAC pada anak di 2 Panti asuhan.

\section{PEMBAHASAN}

Penelitian ini mendapatkan bahwa tidak terdapat hubungan yang bermakna antara kepadatan TDR dengan serangan rhinitis alergi, meskipun banyak tungau yang ditemukan tetapi kebanyakan responden tidak memiliki riwayat rinitis alergi. Hal ini dikarenakan mungkin sistem imun pada tiap individu yang atopi bersifat sangat kompleks dan subjektif, sehingga terdapat perbedaan derajat sensitisasi yang berbeda pada tiap individu. Hal ini dapat diselidiki lebih lanjut dengan pemeriksaan sistem imun tiap individu yang sayangnya tidak dilakukan peneliti dan menjadi salah satu kelemahan dari penelitian ini. Hal ini dapat menjelaskan kenapa tidak ada perbedaan paparan tungau debu rumah dengan status rhinitis alergi.

\section{SIMPULAN}

Tidak terdapat perbedaan bermakna rerata kepadatan tungau debu rumah pada individu dengan riwayat rhinitis alergi dengan individu tanpa riwayat rhinitis alergi.

\section{DAFTAR PUSTAKA}

1. Colloff MJ, Spieksma FTM. Pictorial keys for the identification of domestic mites. Clin Exp Allergy. 1992; 22: 823-30.

2. Millian E, Diaz AM. Allergy to house dust mites and asthma. PR Health Sci J. 2004 Mar; 23 (1): 47-57.

3. Thomas WR, Smith WA, Hales BJ, Milis $\mathrm{KL}$, O'Brien RM. Characterization and immunobiology of house dust mite allergens. Int Arch Allergy Immunol. 2002 Sep;129(1):1-18.

4. El-dib N. House dust mites - what a might a mite do?. Medical Sciences. EOLSS (Encyclopedia of Life Support Systems). 2009; 2: 8. 
5. World Health Organization (WHO). The vector borne human infections of Europe. WHO Regional Office for Europe. 2015;13:92.

6. Yudopranoto K. Perbandingan populasi TDR antara kasur kapuk dengan kasur non kapuk di komplek perumahan PJKA kelurahan Randusari, Semarang Selatan, Jawa Tengah (skripsi). Semarang: Fakutas Kedokteran Universitas Diponegoro; 2016.

7. Ozge A. Allergic rhinitis clinics caused by house dust mites and pollens. Int J Med Sci. 2015; 5(6): 229-31.

8. David P. Allergic rhinitis: definition, epidemiology, pathophysiology, detection, and diagnosis. J Allergy Clin Immunol. 2001 Jul;108(1 Suppl):S2-8.

9. Small $P$, Kim H. Practical guide for allergy and immunology in Canada. Allergy Asthma Clin Immunol. 2011;7(Suppl 1):11.
10. Turner PJ, Kemp AS. Allergic rhinitis in children, Journal of pediatrics and child health. 2012; 48(3): 302-310

11. Utama SD. Hubungan antara jenis kelamin, riwayat alergi keluarga, jenis aeroalergen dan jumlah aeroalergen terhadap manifestasi klinis rinitis alergika ( tesis ). Semarang: Bagian IImu Kesehatan THT-KL Fakultas Kedokteran Universitas Diponegoro; 2010.

12. International Study of Asthma and Allergies of Childhood ISAAC Steering Committee. Phase Three Manual International Study of Asthma and Allergies of Childhood. ISAAC phase three; 2000 (diunduh September 2017). Tersedia dari: http://isaac.auckland.ac.nz/ 